Summer 2004

\title{
Corporate Social Responsibility and Sustainable Development: the European Union Initiative as a Case Study
}

Kristina K. Herrmann

Indiana University School of Law

Follow this and additional works at: https://www.repository.law.indiana.edu/ijgls

Part of the European Law Commons, and the International Law Commons

\section{Recommended Citation}

Herrmann, Kristina K. (2004) "Corporate Social Responsibility and Sustainable Development: the European Union Initiative as a Case Study," Indiana Journal of Global Legal Studies: Vol. 11 : Iss. 2 , Article 6. Available at: https://www.repository.law.indiana.edu/ijgls/vol11/iss2/6

This Note is brought to you for free and open access by the Law School Journals at Digital Repository @ Maurer Law. It has been accepted for inclusion in Indiana Journal of Global Legal Studies by an authorized editor of Digital Repository @ Maurer Law. For more information, please contact rvaughan@indiana.edu.

\section{$\Psi$}

JEROME HALL LAW LIBRARY

INDIANA UNIVERSITY

Maurer School of Law
Blooming ton 


\title{
Corporate Social Responsibility and Sustainable Development: The European Union Initiative as a Case Study
}

\author{
Kristina K. Herrmann*
}

INTRODUCTION

Multinational enterprises (MNEs) are prime drivers of the trend of globalization. As such, they can be held responsible for the success or failure of sustainable development as it relates to continued economic growth without detriment to the environment and exploitation of the human workforce through inadequate labor standards. Corporate social responsibility is an initiative that has been touted as a possible remedy for the ills of globalization that hinder the realization of sustainable development - that is, inequities in wealth, environmental degradation, and unfair labor practices that are endemic of globalization. This Note outlines the concepts of corporate social responsibility, globalization, and sustainable development and describes the role of multinational enterprises with regard to these concepts. It also summarizes previous methods that have proved inadequate in ensuring that sustainable development becomes a reality, including national approaches, international agreements, and private initiatives.

The Note then considers corporate social responsibility as a potential solution that could lead to the achievement of sustainable development. In doing this, the note examines the implications of adopting a corporate social responsibility regime for a multinational enterprise. The European Union's (EU) initiative in creating corporate social responsibility guidelines is used as a detailed case study for scrutinizing the potential of corporate social responsibility as a viable solution. After analyzing the concept of corporate social responsibility and the need for sustainable development in light of globalization, the Note concludes that while corporate social responsibility may indeed lead to the desired goal--

* J.D./M.B.A. candidate, 2004, Indiana University School of Law and Kelley School of Business. The author wishes to express her gratitude to Professors Alfred C. Aman, Jr. and Paul Craig for their guidance and support in writing this Note. She also wishes to recognize the 2002-2003 and 2003-2004 staffs of the Indiana Journal of Global Legal Studies for their encouragement and assistance with this Note. Specifically, she would like to recognize Drew Yoder and David Lundeen for being instrumental in making the publication of this Note a reality. 
sustainable development - a regime such as that proposed by the European Union is likely to fail because of the lack of a strict enforcement mechanism whereby the actions of corporations operating globally can be monitored and socially irresponsible deeds can be penalized.

\section{A. The Bases of Corporate Social Responsibility}

Corporate social responsibility (CSR) has come to the forefront of corporate and economic concerns because of the increasingly globalized nature of business and the so-called New Economy, a knowledge-based, technology-driven environment that has, among other things, affected an increase in stakeholders' access to information. " "The premise of the corporate social responsibility movement is that 'corporations, because they are the dominant institution of the planet, must squarely face and address the social and environmental problems that afflict humankind."'2 As a mode of implementing human rights, labor, and environmental standards, CSR has long been discussed as a possible remedy to the inequalities created and exacerbated by globalization. It considers that a corporation is not just a self-centered profit-making entity, but that the company and its actions are also integral to the economy, society, and environment in which they occur. Directors and officers are becoming ever more aware that CSR may provide human rights, labor, and environmental protections to the communities in which they live and to the people they employ. The business case for such social responsibility among corporations is becoming clearer as globalization progresses. It includes:

- Managing risks

- Protecting and enhancing reputation and brand equity

1. Globalization has also increased the irrelevance of geography in light of the computer, the Internet, and new technologies for the movement of goods. See Cynthia A. Williams, Corporate Social Responsibility in an Era of Economic Globalization, 35 U.C. Davis L. Rev. 705, 731 (2002). Furthermore the "rapid advancement of air traffic has brought the economic community closer together than ever before. But much more importantly, the telecommunications revolution has truly globalized international markets, particularly financial markets." Jost Delbrück, Globalization of Law, Politics, and Markets-Implications for Domestic Law-A European Perspective, 1 IND. J. Global Legal Stud. 9, 17 (1993).

2. Elisa Westfield, Globalization, Governance, and Multinational Enterprise Responsibility: Corporate Codes of Conduct in the $21^{s t}$ Century, 42 VA. J. INT'L L. 1075, 1082 (2002) (citing Paul Hawken \& William McDonough, Seven Steps to Doing Good Business, Inc., Nov. 1993, at 80). 
- Building trust and 'license to operate'

- Improving resource efficiency and access to capital

- Responding to or pre-empting regulations

- Establishing good stakeholder relationships with current and future employees, customers, business partners, socially responsible investors, regulators, and host communities

- Encouraging innovation and new ways of thinking

- Building future market opportunities. ${ }^{3}$

As such, a social responsibility policy can provide value as a strategic part of a firm's daily activities. Under a strategy that integrates socially responsible practices, a company's analysis of profit, return on investment (ROI), or return on equity (ROE) as the bottom-line should be replaced by a "triple bottom-line" approach, encompassing economic, social, and environmental factors. ${ }^{4}$ A company that ignores social and environmental concerns in its activities may have substantial profit or returns in its current state and, therefore, be content to continue its operations at the status quo, but its actions nonetheless have the potential to negatively affect society and the environment. Its potential future profit is thereby diminished when the company does not take a holistic approach to the global business environment.

\section{B. Globalization and the Need for CSR}

Globalization is a widely used term that refers to a multiplicity of external activities. [The term can be used] to refer to flows of ideas, images, goods, services, and people that take place within an integrated whole, without regard to territorial or geographical boundaries and often without the direct agency of the state. ${ }^{5}$

As a preeminent force in today's world, globalization is the trend of denationalization that results from the culmination of political, economic, and non-

3. Jane Nelson, Corporate Social Responsibility: Passing Fad or Fundamental to a More Sustainable Future?, available at http://www.iblf.org/ (last visited Feb. 18, 2004).

4. The "triple bottom line" has also been described as the "triple-P bottom line," referring to "profit ('economic prosperity'), planet ('ecological quality') and people ('well-being')." Jacqueline Cramer, From Financial to Sustainable Profit, 9 Corp. Soc. Resp. \& Envte. MGмt. 99, 102 (2002).

5. John S. Applegate \& Alfred C. Aman, Jr., Introduction: Syncopated Sustainable Development, 9 Ind. J. Global Legal Studies 1, 3-4 (2001). 
economic forces. ${ }^{6}$ Because it encompasses such vital issues, the process of globalization should not progress unmanaged: ${ }^{7}$ it is an indispensable step in the economic and social evolution of the world that, if allowed to go awry, will prevent global sustainable development.

Sustainable development can be viewed in light of the dichotomy between the positive contributions that MNEs make to the economic growth of developing countries and the conflicts of interest brought about by their presence in developing countries. "Sustainable development "calls for economic growth that can relieve the great poverty of less developed countries, based on policies that sustain and expand the environmental resource base.' ... [I]t 'ensures that [humanity] meets the needs of the present without compromising the ability of future generations to meet their own needs."'9 According to the World Commission on Environment and Development, the concept of sustainable development implies some vague

limits-not absolute limits but limitations imposed by the present state of technology and social organization on environmental re-

6. Globalization has been defined as "the process of increasing interconnectedness between societies such that events in one part of the world more and more have effects on peoples and societies far away." The Globalization of World Politics: An Introduction to International Relations 7 (John Baylis \& Steve Smith eds., 1997). Globalization has also been defined as "the process of denationalization of markets, laws and politics in the sense of interlacing peoples and individuals for the sake of the common good." Delbrück, supra note 1, at 11. However, Delbrück points out that globalization does not involve "all major aspects of political, economic, or social life." Id.

7. "According to Joseph Stiglitz[,] ... trade liberalization [must be] balanced in its agenda, process and outcomes, and it must reflect the concerns of the developing world." Richard Welford, Globalization, Corporate Social Responsibility and Human Rights, 9 CorP. Soc. ResP. \& ENvTL. Мямт. 1, 3 (2002).

8. Sustainable development can be defined in several ways. "Sustainable development is a strategy by which communities seek economic development approaches that also benefit the local environment and quality of life." U.S. Department of Energy, Smart Communities Network, at http://www.sustainable.doe.gov/ (last visited Feb. 18, 2004). "Sustainable development is about ensuring a better quality of life for everyone, now and for generations to come." New Zealand Business Council for Sustainable Development, at http://www.nzbcsd.org.nz/definition.asp (last visited Feb. 18, 2004) (quoting the government of the United Kingdom). Sustainable development is "development which meets the needs of the present without compromising the ability of future generations to meet their own needs." U.K. Government, Sustainable Development, at http:// www.sustainable-development.gov.uk/ (last visited Feb. 18, 2004).

9. Applegate \& Aman, supra note 5, at 2 (citing World Comm. On Env't \& Dev., Our Common Future 8, 43 (1987) [hereinafter Our Common Future]). 
sources and by the ability of the biosphere to absorb the effects of human activities. But technology and social organization can be both managed and improved to make way for a new era of economic growth. ${ }^{10}$

As such, "there are 'hard' and 'soft' versions of sustainable development. The hard version would impose real restrictions on the nature and extent of development in the name of sustainability. The soft version treats sustainable development as a set of very general guidelines or goals." 11

"One of the most significant externalities attributed to globalization is the increasing difference in wealth between the industrialized countries of the North and the economic needs of the developing countries of the South."12 As market integration becomes a reality, economic interdependence increases, bringing about reliance on developing countries for resources used in or for production. Furthermore, procurement, production, and trade are becoming increasingly global, with companies using supply chains that reach into and across several nations, establishing subsidiaries in foreign countries, receiving investment from and investing in other nations, and in general, taking advantage of trade liberalization.

In light of these many factors, it is clear that the nature of today's global economy calls for something more than a profit-oriented approach by large and small enterprises alike. As globalization increases, so do inequalities among nations with regard to labor standards and environmental regulations, ${ }^{13}$ decreasing the likelihood that global development is sustainable.

"The impoverishment of a large segment of the international community ... has become a global problem of the first order." ${ }^{14}$ The international community is

10. Our Common Future, supra note 9, at para. 27.

11. Applegate \& Aman, supra note 5, at 2.

12. Id. at 1 .

13. Economic inequalities are also on the rise. See Shahid Yusuf, Globalization and the Challenge for Developing Countries 7 (World Bank Group, DECRG, Working Paper No. 2618,2001 ) ("The income gap between [most developing countries] and the richest nations has continued widening. Forty years ago the per capita incomes of the twenty richest countries were fifteen times the level of the twenty poorest countries. This ratio has now doubled to thirty."). See also Welford, supra note 7, at 4 ("Globalization has caused global conditions of inequality and discrimination to worsen.").

14. Delbrück, supra note 1 , at 14 . 
gradually recognizing the existential threats to the survival of [the planet] posed by the increasing destruction of the human environment. Ozone layer depletion, global warming, water pollution, soil and groundwater pollution, and vast land areas radiated by nuclear waste have reached dimensions that transcend the capabilities of not only individual states but also regional organizations to cope with these threats. ${ }^{15}$

Therefore, directors and officers should examine their companies' roles in the global economy, looking at what negative contributions they make to these disparities among developed and underdeveloped nations and what actions they can take to alleviate the consequences. Globalization thus raises the question of what initiatives should be undertaken to create a global economy in which sustainable development is a reality rather than an unattainable ideal. Globalization renders state regulation of corporate action problematic; therefore, if sustainable development is to be achieved, the corporations themselves must adopt CSR initiatives. Admittedly, these initiatives may not promote a corporation's bottom line in the short term; however, in the long term, the public and the corporation will benefit from CSR because it plays a direct role in ensuring sustainable development.

\section{The Role of MNEs in Globalization and Sustainable Development}

Globalization can be seen as a principal result of the operations of MNEs in the world economy. ${ }^{16}$ MNEs introduce into the global economy technologies, trade, and investments that bring the world closer together, both economically and culturally. Over time, MNEs have garnered significant political and economic influence, stemming mostly from the wealth they produce. Direct investment by MNEs in developing countries exceeds inflows from official aid and net lending by international banks. ${ }^{17}$ Furthermore, the economies of most U.N. Member States are smaller than the annual revenues of the largest MNEs. ${ }^{18}$ The

15. Id. at 15 .

16. "A ... factor contributing to the globalization of markets, closely linked to the high international mobility of capital, goods, and services is constituted by the emergence of transnational corporations." Id. at 17.

17. Ann-Marie Erb-Leoncavallo, The Road from Seattle, U.N. Chronicle, Jan. 2000, at 28.

18. See id. 
wealth, power, and resources of MNEs make them indispensable within their home countries, host countries, and the global community. As such, they can greatly contribute to or detract from the project of sustainable development, depending on the policies they adopt and enforce.

It is important to note that while MNEs are necessarily without home territories and thereby defy compliance with only a single regime, as global non-state actors they can be agents for reform. In short, MNEs are significant global law and policy actors, for better or worse. This, however, is not to say that the state plays no role in the process of globalization.

The state, of course, can and often does facilitate the process of globalization by, for example, providing for property rights and other legal regimes that may encourage economic development. Thus, this is not to argue that states have or can have no role in the processes of globalization. Rather, it is to argue that their role is no longer as central as it once was and, to the extent the state engages in activities that deter globalization, they can often be avoided by multinational actors who simply decide to move aspects of their operations elsewhere or establish parallel, if not competing, legal regimes that cater primarily to their interests. ${ }^{19}$

Thus, MNEs are often more powerful than the states in which they conduct business. In light of this power, the "increasing and seemingly irreversible interconnections and interdependence that the [flows of globalization] can trigger has [sic] enormous potential to bring greater development, but the role of sustainability remains to be seen." 20

MNEs are thought to make a positive contribution to the development of underdeveloped countries through their investments, products, and services. ${ }^{21}$ More specifically, MNEs contribute to the development of less-developed countries by providing access to technological and management expertise, investment and employment, and training for all levels of the employment hierarchy. However, the

19. Alfred C. Aman, Jr., The Globalizing State: A Future-Oriented Perspective on the Public/Private Distinction, Federalism, and Democracy, 31 VAnd. J. Transnat'L L. 769 n.34 (Oct. 1998).

20. Applegate \& Aman, supra note 5, at 4.

21. See Charles W. Hill, The Political Economy of Foreign Direct Investment, in INT'L Bus., available at http://www.mhhe.com/ (last visited Feb. 15, 2004). 
lack of both absolute limits within the idea of sustainable development and of an appropriate regulatory system and strong financial conditions in the host country can counteract MNEs' positive contributions, causing the companies' presence to be detrimental rather than beneficial to the country. ${ }^{22}$ In this way, MNEs exploit the softness of the sustainable development concept and effectively work against sustainable development in practice. The presence of MNEs in a developing country can also create conflicts of interest. As a profit-maximizing enterprise, a company is unlikely to evaluate the interests of the host country in economic and social development as it conducts its business. ${ }^{23}$ Instead, it will continue to pursue its self-interested objectives such as maximizing ROI or ROE, gaining market share, cutting costs, or increasing long-term competitiveness.

While a host country may encourage foreign direct investment by MNEs through policy, it faces concerns as to whether MNEs will create relationships with the regional economy or will simply exploit local labor conditions and the environment, always remaining primed to abandon the country in favor of a cheaper source of labor, a more relaxed regulatory environment, or an otherwise more attractive host country. ${ }^{24}$ Lower environmental and labor standards of foreign direct investment targets are appealing to MNEs because such lenience boosts production efficiency and increases competitiveness in the short term, thereby enhancing bottom line profits and productivity. ${ }^{25}$ Thus, host countries may regret the decision to attract foreign direct investment when foreign companies exploit or violate the country's lax or poorly enforced labor or environmental policies, thereby causing detriment to the host country and its society, but at the same time reaping the benefits of increased profits due to lesser regulation. ${ }^{26}$ This is prime evidence that the

22. See id. An MNE's presence in a developing country is not entirely detrimental; however, along with the benefits of the MNE's presence come costs, such as exploitation of weak labor and environmental standards. It is these costs that threaten the attainment of sustainable development.

23. See id.

24. See Westfield, supra note 2, at 1082 (citing David Montgomery, Labor Rights and Human Rights: A Historical Perspective, in Human Rights, Labor Rights, and International Trade (Lance A. Compa et al. eds., 1996)).

25. See id. at 1081 .

26. See Novartis Foundation for Sustainable Development, The Effect of Multinational Companies on Development, at http://www.foundation.novartis.com/multinational_companies.htm (last visited Feb. 9, 2004). 
international commitment to the environmental protection element of sustainable development has eroded because, in this era of globalization, 'sustainable development' has not yet advanced beyond being a form of words designed to achieve a political compromise. If sustainable development is to flourish as a means of providing a healthy environment for future generations, it must have real content and meaning-conceptual, technological, financial, and legal—for a global economy and society. ${ }^{27}$

"While sustainable development has been enthusiastically adopted by much of the world as the standard for judging environmental and development policy, there are no institutional structures in place to implement the limitations and obligations essential to achieving real changes ...."28

\section{Methods of Protection that Have Proved Inadequate}

Where to place the responsibility for the protection of environmental rights and the establishment of fair labor standards such that sustainable development is promoted has been the subject of much debate.

\section{A. National Approaches}

The traditional view holds that the state is responsible for safeguarding such rights. ${ }^{29}$ In conformance with this view, state governments have national constitutions or legal codes that guarantee these rights. These state governments often also have entered into bilateral agreements with other states to demand mutual respect of rights and regulations. ${ }^{30}$ Although these tools may be valuable within the boundaries of a nation, problems of enforcement against corporations operating internationally arise because national laws do not apply globally. Thus, the traditional view does not provide optimal protection for human rights and the environment in light of globalization.

27. Applegate \& Aman, supra note 5, at 4.

28. Id. at 5 .

29. See Erin Elizabeth Macek, Scratching the Corporate Back: Why Corporations Have No Incentive to Define Human Rights, 11 Minn. J. Global Trade 101, 102 (2002).

30. See id. at 102. 


\section{B. International Agreements}

To overcome the limitations posed by national regulations, many countries have adopted international agreements relating to labor practices and environmental standards that transcend national boundaries. Examples of such international agreements include the U.N. Global Compact; ${ }^{31}$ I.L.O. International Labor Standards; ${ }^{32}$ OECD Guidelines for Multinational Enterprises; ${ }^{33}$ International Covenant on Economic, Social and Cultural Rights; ${ }^{34}$ and International Covenant on Civil and Political Rights. ${ }^{35}$ Despite the number of countries that have acceded to these agreements, the agreements are of dubious value because they lack enforcement mechanisms and sanctions for nonconforming behavior.

\section{Private Initiatives}

The use of private initiatives, or self-governance, is a third possible way to establish global regulations of the environment, human rights, and labor standards. In response to global demand, some MNEs have voluntarily adopted the use of codes and guidelines to improve working conditions and environmental practices in countries where they do business. ${ }^{36}$ There is great variation, however, among such private initiatives with regard to the issues involved, implementation, and enforcement. Developing countries compete for MNEs' investments; therefore, MNEs can freely choose where to conduct their business. Such competition among developing countries causes those countries to create corporate-friendly legal environments. In light of this reality, MNEs can influence a country's social and environmental practices, forcing the change of a country's practices or policies by refusing to invest in a country if its policies are

31. See About the Global Compact, at http://www.unglobalcompact.org (last visited Feb. 15, 2004).

32. See International Labor Organization, International Labor Standards, at http://www.ilo.org/ (last modified Jan. 11, 2000).

33. See OECD Guidelines for Multinational Enterprises, available at http:/www.union-network .org/UNIsite/In_Depth/Interna_Relations/OECDGuidelines.pdf (last revised 2000).

34. See ICESCR: International Covenant on Economic, Social and Cultural Rights, available at http://www.iwtc.org/ICESCR.html (entered into force 1976).

35. See International Covenant on Civil and Political Rights, March 23, 1976, available at http:// www.unhchr.ch/html/menu3/b/a_ccpr.htm.

36. See Westfield, supra note 2, at 1098. 
adverse to the goals of the company. ${ }^{37}$ Despite the proliferation of private initiatives, exploitation of the environment and abusive or exploitative labor practices continue unabated. Such exploitation can be attributed to the nature of competition: placing voluntary responsibility on corporations to promote and protect fair labor practices and defensive environmental regulations will not succeed "because the incentive to make a profit and remain competitive will potentially persuade a corporation to disregard the principles" it has voluntarily adopted. ${ }^{38}$

\section{A Potential Solution: Corporate Social Responsibility}

Industrialized nations that serve as the home bases for MNEs, and thereby further the trend of globalization, are in the best position to control MNEs and their effect on globalization. Therefore, those nations must "ensure that the path of globalization fairly balances the values of free market economics, democracy, and human rights, while accommodating such vital concerns as the protection of the environment" by creating standards for behavior applicable to MNEs as well as to purely domestic businesses. ${ }^{39}$ MNEs' abuse of developing countries and their lenient standards makes the sustainability of development within those countries questionable. As none of the foregoing methods of implementing protections for human rights, labor, and environment has proved successful, it is clear that a more proactive approach is necessary in order to guarantee global sustainable development.

\section{A. The Creation of a CSR Regime}

A corporate social responsibility regime is a potential solution that may lead to the realization of sustainable development. Its creation will require four stages: setting standards; monitoring compliance with standards and exposing abuses; creating binding legal obligations; and enforcing those binding laws. ${ }^{40}$

37. Some companies have taken their initiatives so seriously as to have caused their operations to withdraw from countries where they could otherwise operate profitably. See id.

38. Macek, supra note 29, at 124.

39. Alex Y. Seita, Globalization and the Convergence of Values, 30 CoRnELL. INT'L L.J. 429, 432 (1997).

40. William H. Meyer \& Boyka Stefanova, Human Rights, the UN Global Compact, and Global Governance, 34 CornelL INT'L L.J. 501, 514 (2001). 
Social responsibility should accompany power $;^{41}$ therefore, the view that MNEs should play a significant role in the protection of rights through a CSR regime is correct. However, to be effective in bringing about sustainable development, the regime must be the product of national and international initiatives and must be carried out by corporations operating globally. An international, cooperative approach is thus necessary to allow for the controlled furtherance of globalization and accompanying sustainable development. This cooperative approach will require MNEs to change their core values to incorporate protection of the environment and fair labor standards.

\section{B. CSR Requires Change in a Corporation's Strategy}

While many MNEs currently conceptualize their success as solely related to bottom line profits and productivity, this is a short-sighted view. Instead, MNEs should focus on long-term strategies that will sustain a global system. ${ }^{42}$ That is, MNEs should have sustainable development as their goal. ${ }^{43}$ Sustainable development is in MNEs best interest as it will lead to long-term sustained productivity, profits, and overall success. ${ }^{44}$ The long term success of MNEs in the global marketplace relies on the implementation of successful policies that will allow for the realization of global sustainable development. Should sustainable development not be achieved, the lives of MNEs will be shortened as will the existence of the planet as a whole as it is today. While higher levels of employment and cheaper products may result over the short term, accompanying those will be more polluted air and water, diminished natural resources, and intensely unfair and unhealthy working conditions.

The implementation of socially responsible policies by MNEs is critical to sustainable development because of the crucial role MNEs play in the economy.

41. See Joel Makower, Beyond the Botrom Line 30 (1994) (suggesting that while the goal of a corporation is to maximize profit for the benefit of shareholders, social responsibilities automatically attach to it because of its considerable power in the global marketplace).

42. See Westfield, supra note 2 , at 1082.

43. This is not to say that all officers and directors of MNEs ignore the environment and seek out unfair (and to them advantageous) labor standards. It is to say, however, that MNEs, as profitseeking institutions at the core, necessarily do not seek the benefit of the planet or the human population as a whole. In fact, their goals sometimes come into direct conflict therewith.

44. Sustainable business practices have been defined as requiring "a systematic link between their financial profitability and their ecological and social performance." Cramer, supra note 4, at 99. 
Based on the traditional short-term, profit-oriented view, however, many MNEs currently use the Porter's Five Forces Model, under which a company examines supplier power, ${ }^{45}$ barriers to entry, ${ }^{46}$ threat of substitutes, ${ }^{47}$ buyer power, ${ }^{48}$ and the degree of rivalry ${ }^{49}$ in assessing its competitiveness within an industry. However, directors and officers of MNEs should think beyond the scope of this model to examine competitiveness in planning for the longer term. They should examine five factors specific to each country in which they are operating, in addition to using the Porter analysis: economic, ${ }^{50}$ political/legal, ${ }^{51}$ supplier/technological, ${ }^{52}$ social/demographic, ${ }^{53}$ and environmental factors. ${ }^{54}$ Such analysis allows for a more holistic understanding of the global environment in which the

45. Assessment of supplier power involves factors such as supplier concentration, importance of volume to supplier, differentiation of inputs, impact of inputs on cost or differentiation, switching costs of firms in the industry, presence of substitute inputs, threat of forward integration, and cost relative to total purchases in industry. See QuickMBA, Porter's Five Forces, available at http:// www.quickmba.com/strategy/porter.shtml (last visited Feb. 15, 2004).

46. Assessment of barriers to entry involves factors such as assessment of absolute cost advantages, proprietary learning curve, access to inputs, government policy, economies of scale, capital requirements, brand identity, switching costs, access to distribution, expected retaliation, and proprietary products. See id.

47. Assessment of the threat of substitutes involves factors such as switching costs, buyer inclination to substitute, and price-performance trade-off of substitutes. See id.

48. Assessment of buyer power involves factors such as bargaining leverage, buyer volume, buyer information, brand identity, price sensitivity, threat of backward integration, product differentiation, buyer concentration versus industry, substitutes available, and buyers' incentives. See id.

49. Assessment of degree of rivalry involves factors such as exit barriers, industry concentration, fixed costs/value added, industry growth, intermittent overcapacity, product differences, switching costs, brand identity, diversity of rivals, and corporate stakes. See id.

50. Economic factors to be considered include stability of economy, stability of currency, rate of inflation, methods of attracting FDI, and opportunities within the market for growth or development. Professor Idalene Kesner, Lecture at the Kelley School of Business (MBA Core, Fall 2001)(on file with author).

51. Political and legal factors to be considered include existing government policies (i.e. protectionist), tariffs, existence of national and international regulations, and the existing legal system and enforcement mechanisms. Id.

52. Supplier and technological factors to be considered include infrastructure, use and availability of the Internet and other technologies, and legal regulations applicable to suppliers. Id.

53. Social and demographic factors to be considered include education and income levels, population, cultural affinities and preferences, current and expected worker conditions, and language barriers. Id.

54. Environmental factors to be considered include environmental regulations and enforcement, presence of natural resources, and country policies relating to environment. Id. 
MNEs operate and of the specific economy the MNE is considering for possible entry.

However, this inclusive analysis is worthless without a change in the corporation's strategy and goals. With a purely profit-oriented strategy, the five additional factors do not add value in appraising a company's competitive position. But if the strategy takes into account economic changes wrought by globalization and implements a socially responsible value system within the corporation, the additional five factors will contribute greatly to the company's long-term profitability and competitiveness. Such strategy will not only perpetuate the MNE's existence, but will also contribute to the sustained development of the global economy. As one author has stated, "as the private sector has grown in size, influence and reach, so too have the demands for increased corporate responsibility." ${ }^{\text {. } 55}$

\section{The Relationship between CSR and Sustainable Development}

A well-implemented and strongly enforced CSR policy is key to sustainable development. CSR is a comprehensive notion that takes into account economic, social, and environmental concerns and, at the same time, protects the interests of all stakeholders by requiring greater transparency. Inherent in social responsibility of corporations is the understanding among corporate managers that their business decisions must be made with consideration of a "wider range of constituents than shareholders, and thus [they] ought to consider the implications of their actions on employees, consumers, suppliers..., the community, and the environment." ${ }^{56}$ Stakeholders may also include civil society organizations and other non-governmental organizations (NGOs). This stakeholder view of a corporation's social responsibility requires a constant dialogue between corporate decision-makers and the company's various stakeholders. In the end, a wellimplemented and well-enforced CSR strategy that utilizes a constant dialogue with stakeholders should result in:

(i) respect and care for the community of life,

(ii) improvement in the quality of human life,

(iii) change in personal attitudes and practices,

55. Nelson, supra note 3 , at 37.

56. Williams, supra note 1 , at 716 (citation omitted). 
(iv) empowerment of communities to care for their own environments,

(v) provision of a [global] framework for integrating development and conservation, and

(vi) creation of a global alliance. ${ }^{57}$

All of these lead to long-term value creation for the corporation, its stakeholders, and the communities in which it operates.

However, it is important to note that the implementation of a CSR policy will initially cause the corporation to incur additional costs with no immediate return. That is, the corporation may have to choose more expensive inputs and production techniques to protect the environment or pay laborers more and provide improved working conditions, all of which consume resources and detract from the bottom line by increasing operating costs. CSR may also require the corporation to forego certain opportunities that are not aligned with the company's values and principles as found in its CSR policy. ${ }^{58}$ But, "having a set of clearly stated values, principles and policies, and mechanisms for measuring performance and ensuring internal and external accountability for these"59 is crucial to the corporation's contribution to sustainable development in the globalized world. MNE managers should seek to ignore the short term costs of instituting and adhering to a CSR program in favor of thinking about the long term benefits thereof, both for the company and the world..$^{60}$

Although CSR policies will vary among industries and among companies within those industries, three main areas that CSR policies will influence have been identified. First, CSR requires the implementation of socially responsible core business activities that minimize negative impacts and optimize positive impacts. This includes compliance with international standards concerning the environment, labor, and human rights. Companies can also be more proactive in controlling the risks and social costs associated with their activities. Second,

57. Peter R. Downey, The Essential Stakeholder Dialogue, Corp. Soc. Resp. \& Envtl. Mgmt. 37, 38 (2002).

58. See Nelson, supra note 3, at 37.

59. Id.

60. Concededly, investors may dislike the decision of a company to adopt socially responsible policies as it will mean less ROI and ROE for them. CSR thus calls for socially responsible investors as well as corporations, which may require education of shareholders. The reality of an investor accepting less return in exchange for socially responsible policies sounds inane; however, see discussion infra of the increasing popularity of indexes for socially responsible investment. 
companies should institute poverty-focused social investment and philanthropy programs such that their contributions to host communities and social causes become integral to the company's strategy. Third, CSR requires corporations to become engaged in public policy dialogues and institution-building with the goal of fostering an environment that is conducive to both profitable business and sustainable development. This requires the establishment of trade and business associations or corporate leadership networks that will address issues beyond immediate commercial interests. ${ }^{61}$ However, as stated previously, MNEs cannot be relied upon to implement CSR policies individually due to concerns for commonality among protections, implementation, and evaluation mechanisms. Furthermore, short term profit motivations will be a countervailing force to the adoption of CSR policies for all but the most community-minded corporations.

\section{European Union Initiatives as a Model for CSR}

While the United States and other industrialized countries have recognized the importance of CSR, the European Union provides a prime case study of the fastidious debate required within a nation or group of nations to create an overarching CSR policy that includes already existing multinational as well as local and company-specific initiatives. The EU is attempting to create common CSR guidelines for MNEs operating both within the EU member states and in other countries, in order to standardize the regulations followed, the methods of implementation, and the mechanisms for measuring performance. Standardization will lead to the global protection and enhancement of human rights, labor practices, and environmental controls, all of which will result in sustainable development in the long term.

\section{A. The European Council in Lisbon}

The European Union realized that it is facing a paradigmatic shift resulting from globalization and the challenges of a technology-driven, knowledge-based economy; therefore, the European Commission (the "Commission") called a special meeting on March 23-24, 2000, in Lisbon to settle on a new strategic goal for the EU. The changes wrought by globalization and the New Economy compelled the EU to set as its new goal that of becoming "the most competitive and 
dynamic knowledge-based economy in the world, capable of sustainable economic growth with more and better jobs and greater social cohesion." ${ }^{62}$ The European Council in Lisbon recognized as necessary to the accomplishment of this goal a strategy with the following objectives:

Preparing the transition to a knowledge-based economy and society by implementing better policies for the information society and research and development, as well as by stepping up the process of structural reform for competitiveness and innovation and by completing the internal market; modernising the European social model, investing in people and combating social exclusion; [and] sustaining the healthy economic outlook and favourable growth prospects by applying an appropriate macro-economic policy mix. ${ }^{63}$

A further objective espoused by the Council in Lisbon to help the EU transition to a sustainable, dynamic, knowledge-based economy is the development of an active employment policy, including the implementation of best practices in many areas, such as lifelong learning initiatives, equal opportunity employment policies, and social inclusion. The goal of CSR is to achieve and sustain objectives such as these. In response to concerns about the role of the $E U$ in formulating a CSR regime, the European Parliament has suggested that "[ $t$ ]he main contribution of a European approach to CSR would be to add value to and complement existing activities by providing an overall European framework on CSR practices, and by supporting best practice approaches to evaluation and verification of CSR practices." ${ }^{4}$

\section{B. The Response to Lisbon: The Green Paper}

As such, the Lisbon Summit prompted the position of CSR as a feature on the agenda of the Stockholm Summit of March 23-24, 2001, where the focus was on finding strategies that will assist in attainment of the goals articulated in

\footnotetext{
62. Lisbon European Council, March 2000, available at http://ue.eu.int/ (emphasis omitted).

63. Id.

64. Jan Andersson, Written Question P-1658/01 to the Commission, 2001 O.J. (C 364 E/187) 169 , available at http://europa.eu.int/.
} 
Lisbon. In Stockholm, the European Council welcomed business initiatives to promote CSR. Although CSR was not a priority in Stockholm, the Commission announced its intention to present a Green Paper in June 2001 concerning CSR in an effort to stimulate debate and promote further CSR initiatives. ${ }^{65}$ On July 18, 2001, the Commission issued a Green Paper entitled "Promoting a European Framework for Corporate Social Responsibility". ${ }^{66}$ As discussed in Stockholm, the purpose of this Green Paper is to launch a wide debate about how a European approach to CSR should be developed so as best to promote the notion of CSR both at European and global levels. As a possible positive contribution to the strategic goal determined at Lisbon, the Green Paper defines CSR in the following manner:

By stating their social responsibility and voluntarily taking on commitments which go beyond common regulatory and conventional requirements, which they would have to respect in any case, companies endeavour to raise the standards of social development, environmental protection and respect of fundamental rights and embrace an open governance, reconciling the interests of various stakeholders in an overall approach of quality and sustainability. ${ }^{67}$

More concisely, CSR is defined in the Green Paper as "a concept whereby companies decide voluntarily to contribute to a better society and a cleaner environment." ${ }^{\prime 6}$ It is described further as a responsibility that is "expressed towards employees and more generally towards all the stakeholders affected by business and which in turn can influence its success." ${ }^{69}$

In an attempt to spur debate about CSR, the Green Paper makes several observations about the concept. It recognizes that a corporation's focus is the generation of profits; however, it points out that social and environmental objectives

65. Stockholm European Council, March 2001, available at http://europa.eu.int/comm/ stockholm_council/(last visited Feb. 10, 2004).

66. Green Paper: Promoting a European Framework for Corporate Social Responsibility, available at http://europa.eu.int/ (last visited Feb. 15, 2004)[hereinafter Green Paper].

67. See id. at 3 (executive summary).

68. Id. at 4.

69. Id. 
should be of primary importance as well. "European companies see themselves as an integral part of society, [so] as they act in a socially responsible way; consider profits to be the main goal of the company but not its only 'raison d'être;' and opt for long-term thinking on strategic decisions and investment." ${ }^{\prime 0} \mathrm{Ac}$ cording to the Green Paper, CSR can be of direct economic value and therefore should be treated as an investment rather than a cost. Furthermore, it should be part of the core business strategy, management, and operations. It should be pursued internationally as well as in Europe, throughout a company's entire supply chain. CSR should be developed through analyzing, benchmarking, and then implementing best practices gathered from other industry players. Corporations should form partnerships with NGOs, local authorities, and bodies that manage social services so as to strengthen their social responsibility. Most importantly, the Green Paper suggests that businesses should become socially responsible in their operations both within the EU and abroad as "a proactive approach to sustainable development." 71

The Green Paper does not ignore the global perspective: it acknowledges that a European approach to CSR must incorporate the various extant initiatives, such as the U.N. Global Compact, the I.L.O.'s Declaration of Principles concerning Multinational Enterprises and Social Policy, and the OECD Guidelines for Multinational Enterprises. Although these global initiatives are not legally binding, the European approach agreed upon after a debate spurred by the Green Paper should complement and integrate these initiatives as well as other existing CSR activities within companies. ${ }^{72}$ The Green Paper proposes a twofold European approach:

[to provide] an overall European framework, aimed at promoting quality and coherence of corporate social responsibility practices, through developing broad principles, approaches and tools, and promoting best practice and innovative ideas; [and to support] best practice approaches to cost-effective evaluation and independent verification of corporate social responsibility practices, thereby ensuring their effectiveness and credibility. ${ }^{73}$

70. Id.

71. Id. at 5 .

72. Id. at 6.

73. Id. 
In examining the concept itself, the Green Paper describes CSR as having both internal and external dimensions. With regard to the internal dimension, the Paper says the following:

Within the company, socially responsible practices primarily involve employees and relate to issues such as investing in human capital, health and safety, and managing change, while environmentally responsible practices relate mainly to the management of natural resources used in the production. They open a way of managing change and reconciling social development with improved competitiveness. ${ }^{74}$

With regard to the external dimension of CSR, the Paper notes that:

Corporate social responsibility extends beyond the doors of the company into the local community and involves a wide range of stakeholders in addition to employees and shareholders: business partners and suppliers, customers, public authorities and NGOs representing local communities, as well as the environment. ${ }^{75}$

Furthermore, CSR is not limited to Europe: "In a world of multinational investment and global supply chains, corporate social responsibility must also extend beyond the borders of Europe. Rapid globalization has encouraged discussion of the role and development of global governance: the development of voluntary CSR practices can be seen as contributing to this." 76

Thus, CSR involves the integration of companies into their local, national, and global settings. At the same time, the Green Paper recognizes the strong human rights dimension of CSR, particularly with regard to global operations and supply chains.

What CSR comprises will differ from company to company and industry to industry. "Companies' approaches in dealing with their responsibilities and relationships with their stakeholders vary according to sectoral and cultural differences." 77 Implementing CSR practices into a corporation's strategy is a holistic

74. Id. at 8 .

75. Id. at 11.

76. Id.

77. Id. at 15. 
process and requires several steps, starting with adopting a mission statement and code of conduct or credo, both of which describe the company's purpose, values, and responsibilities to its stakeholders. After that, the company must translate these ideals into actions within the company's strategy and daily decisions. This requires adding social policy into every aspect of the company's operation and then evaluating the corporate performance in accordance with that policy. Evaluation may involve the creation of community advisory committees or continuing education programs, among other methods. ${ }^{78}$

Successful implementation of CSR in a company's strategy therefore requires a paradigm shift at the core of the business. Managers must learn to think in ways other than those they are accustomed to, and employees and other stakeholders have greater incentive to become personally involved in the business. Furthermore, the proliferation of CSR among corporations has already led to the creation of social indexes on which those corporations are listed. Such indexes allow for socially responsible investment (SRI), which, according to the Green Paper, has "experienced a strong surge in popularity among mainstream investors." 79

\section{European Response to the Green Paper}

Following the issuance of the Green Paper, a European Presidency conference was held about CSR on November 27-28,2001. The aim of the conference was to promote CSR on the EU's political agenda and to deepen the discussion among stakeholders. In the conference, the European authorities called for transparency and questioned their roles ${ }^{80}$ Soon thereafter, the Council issued a Resolution in support of the Green Paper on CSR.$^{81}$ On July 2, 2002, the Commission issued a Communication on CSR proposing a multi-stakeholder forum to debate issues such as reporting, assurance and labels, and to develop common guidelines for these issues by mid-2004. ${ }^{82}$ In response to this Communication,

78. Green Paper, supra note 66.

79. Id. at 20 .

80. See Conference on the Belgian Presidency of the European Union, available at http:// www.socialresponsibility.be/reports_en.html (last visited Feb. 15, 2004).

81. See Council Resolution on Follow-up to the Green Paper on Corporate Social Responsibility, available at http://www.europa.eu.int/ (last visited Feb. 15, 2004).

82. See Communication from the Commission, Corporate Sacial Responsibility: A Business Contribution to Sustainable Development, July 2, 2002, available at http://europa.eu.int/. 
the EU Multi-Stakeholder Forum on CSR (CSR EMS Forum) was launched on October 16, 2002. Its function is to gather the business community, trade unions, civil society organizations, and other stakeholders to promote innovation, transparency, and convergence of CSR practices and instruments.$^{83}$ More specifically, the goal of the CSR EMS Forum is to improve "knowledge about the relationship between CSR and sustainable development...by facilitating the exchange of experience and good practices and bringing together existing CSR instruments and initiatives." 84

In its press release of July 27,2002, the Commission stated that it views CSR as the correct response to the changes in society and economy resulting from globalization, technology, social change, and environmental pressures. ${ }^{85}$ In light of this, and because of the amount of attention expended on the topic of CSR recently, it is apparent that the EU is aware of the value of CSR. For that reason, the EU has made CSR part of its strategy for sustainable development. ${ }^{86}$

\section{The Importance of CSR to the EU}

CSR has significant value in the changing business and social environment of today's global economy. The Commission has recognized that CSR will assist the EU in achieving the goal set forth in the Lisbon Summit-that of the EU becoming "the most competitive and dynamic knowledge-based economy in the world"-in that CSR combines "business profitability with the twin concepts of sustainability and accountability...[and helps companies to strike] the appropriate balance between flexibility and responsibility in creating a friendly business environment." 87

The EU has recognized that

competitiveness and profitability, as the basis for long-term survival, are the essential prerequisites for companies accepting social

83. See EUROPA, Corporate Social Responsibility Multistakeholder Forum, available at http:// www.europa.eu.int (last visited Feb. 15, 2004).

84. Id.

85. Press Release, European Commission, Social Accountability International (July 27, 2002), available at http://www.cepaa.org.

86. Id. at 2.

87. Id. at 1 . 
responsibility. The connection between business success and social responsibility must be seen in the following terms: social responsibility together with economic success contribute to a company's sustainability. It is therefore important to persuade companies to see social responsibility as a long-term undertaking, as a strategic investment in policies such as marketing, management tools and activities. $^{88}$

The EU has thus framed CSR as a long-term strategy for sustainable profitability and growth for both MNEs and nations. The EU approach to CSR has been to achieve consensus among EU countries and MNEs that have their home base in the EU. For such cooperation to occur, dialogue between companies, stakeholders, and public authorities is necessary, as are management tools to implement CSR policies. ${ }^{89}$

\section{A. The Necessity of Public-Private Partnerships}

CSR provides a challenge to companies because it requires a change from the traditional manner of managing and running a business. It demands commitment to being a global corporate citizen within the company itself as well as within its operating environments. The modern ideal of a corporation as being wholly independent from its surroundings must be altered $:{ }^{90} \mathrm{CSR}$ requires the formation of stronger public-private partnerships in order to play a role in sustainable development. Partnerships between businesses, public institutions, and civil society address global developmental challenges by delivering value for both society and the businesses involved. ${ }^{91}$ For the formation of such partnerships to become a reality, there must be some business incentive to the partners involved, such as the achievement of social and environmental objectives; increased access to resources; upgraded access to information; risk management;

88. Opinion of the Economic and Social Committee on the Green Paper: Promoting a European framework for Corporate Social Responsibility, available at http:/europa.eu.int/.

89. See Press Release, Corporate Social Responsibility: EU launches dialogue on best practice for multinationals, May 11, 2001, available at http://europa.eu.int/.

90. See Jouni Korhonen, The Dominant Economics Paradigm and Corporate Social Responsibility, 9 Corp. Soc. Resp. \& Envtr. Mgmt. 67, 70 (2002).

91. See Business for Social Responsibility, Working with Multilaterals, available at www.bsr.org/ multilaterals.pdf. 
growth of human capital; improvement of operational efficiency; attainment of organizational innovation; and enhancement of reputation and credibility. ${ }^{92}$ These results will serve to incentivize MNEs and non-corporate entities alike to create partnerships for sustainable development by establishing and working toward common goals. The potential outcomes of these partnerships are varied: resource mobilization, increased awareness, redesign of global governance, trade and investment liberalization, strengthening of labor standards, and establishment of generally accepted principles for measuring and reporting on sustainability. ${ }^{93}$ The Economic and Social Committee has recognized the importance of creating a better balance between "'shareholder value' and the interests of workers and their representatives and other stakeholders-customers, suppliers, the local community and society." ${ }^{\text {" }}$

However, such partnerships and initiatives will not come about by themselves. There must be 'some motivation for MNEs to adopt socially responsible policies. The EU has recognized this and has therefore called for legislation involving the development or adaptation of standards "to ensure the respect of fundamental social rights and to respond to new challenges. Such standards can also result from agreements between the social partners at the European level." 95 These legislative efforts should be combined with public promotion that makes clear the advantages of taking a socially responsible approach to business. In short, they should show that "taking account of sustainability can enhance business performance in a number of ways such as reducing operating costs and improving efficiency, developing innovative products, improving reputation and brand value, recruiting and retaining good staff and reducing a company's liabilities through integrated risk management." 96

92. Id.

93. Id.

94. Opinion of the Economic and Social Committee on the Green Paper, supra note 88.

95. Commission Communication, European Scrutiny Committee, Social Policy Agenda (June 28, 2000), available at http://www.parliament.the-stationery-office.co.ok/.

96. See I-Manifest, Global CSR Reporting Increases (October 2003), available at http:// www.manifest.co.uk/. 


\section{B. The Use of Best Practices}

Implementation of legislation should be achieved with management tools determined though an analysis of best practices. ${ }^{97}$ Both the EU and MNEs must take into account that "[l] ocal cultural features and legal environments have a direct impact on the development of CSR." 98 Although the Commission has ignored this in its Green Paper, the Economic and Social Committee has highlighted it as important. .99 This Committee has commented that "[d]istinctions must be drawn between the different geographical levels of action (local, national, European and global), between developing and industrialised countries, between large multinational corporations, [MNEs] and micro-businesses, and between sectors." ${ }^{100}$ When analyzing and implementing best practices or legislation, these distinctions must be at the forefront of consideration by both the government and MNEs. Furthermore, the type of enterprise involved may not be the traditional kind envisioned in the Green Paper: "[t]he Commission's observations also assume a traditional hierarchical company structure, whereas new types of structure and work organisation (part-time, teleworking, virtual companies, etc.) should also be considered."101

\section{CSR as an Entirely Voluntary Approach}

The voluntariness of CSR has been the topic of much debate after the publication of the Green Paper. A majority of opinions views the voluntary nature as essential to the success of CSR policies; at the same time, they condone the use of an overarching framework to ensure commonality of rights protected and standards used. Because CSR by definition surpasses legal requirements, it can only be voluntary. ${ }^{102}$ Furthermore, for transnational corporations to practice their social commitment effectively, it is imperative that they have the flexibility to choose those approaches that best suit their individual situation and that "best reflect their possibilities for dealing with business partners in developing countries." 103 Within

97. See id.

98. Opinion of the Economic and Social Committee on the Green Paper, supra note 88, at 45.

99. See id.

100. Id.

101. Id.

102. See id.

103. Id. at 47 . 
a general CSR framework such as that proposed by the Green Paper, MNEs can focus on those issues that are particularly pertinent to their industry, their competitive strategy, and the markets in which they operate. 104 "While one company will prefer external monitoring or certification, another will find internal action and monitoring more appropriate. What ultimately counts is whether the initiative is actually effective." 105

However, an overarching framework such as that proposed by EU initiatives is indeed necessary: "[c]ompanies are a part of society and operate in a social environment that is shaped by laws and collective agreements which regulate the labour market, reconcile interests on both sides and protect workers." 106 In the absence of a legal framework for MNEs to follow, global social and environmental policy will suffer. The presence of an overarching framework, however, will lead to an ethos in which CSR is secure. It will also lead to compensation by MNEs for the failures of governments of countries in which they are operating: the MNEs' social responsibility policy will require them to do more than just what they are legally obliged to do by the host country's laws.

\section{Conclusion}

As corporations operate in an increasingly interconnected world, they gain immense power and influence such that it is easy for them to exploit developing countries to increase their competitive advantage through low cost production, low cost procurement, etc. At the same time, developing countries lower their labor standards, environmental regulations, and human rights protections to entice MNEs' business and money away from nations with stricter standards. While this brings prosperity to developing countries in the short term, it implicates the larger issue of whether development based on this concurrent exploitation by MNEs and race-to-the-bottom by developing nations is sustainable. Many countries have recognized the need to place responsibility for sustainable development on the shoulders of corporations. To the EU in particular, it is clear that sustainable development is not only improbable, but impossible, should globalization be permitted to continue without a framework to shape its future.

104. "Companies should have the option of developing tailored, sector-specific and particularly efficient approaches that are appropriate to their specific situation." Id.

105. Id. at 47.

106. Id. at 48 . 
The EU has therefore begun the lengthy process of creating a corporate social responsibility ethos by which MNEs must abide, both when operating within the EU and outside.

While this CSR framework is still in its infancy in the EU, the serious discussion that has occurred and continues currently in response to the Green Paper is a tremendous step toward the reality of sustainable development. As a large block of powerful nations, the EU is likely be imitated by many countries with regard to its CSR initiative, which will help sustainable development to become the goal not only of several nations, but of the world. Corporate social responsibility, when implemented such that it permeates the strategy and core business of an MNE, will safeguard human rights, ensure that protective labor standards are instituted and followed, and enforce environmental regulations. CSR will lead MNEs to sustainable profitability and efficiency through the attraction and retention of skilled workers and the stability of environmental resources. Furthermore, it will instill in developing countries trust in MNEs and the desire to adopt similarly protective regulations of human rights, labor practices, and the environment. Put together, the inevitable long-term consequence is sustainable development.

However, the voluntary nature of the EU's CSR initiative calls its efficacy into question. Because implementation of a CSR policy will likely reduce an MNE's short term revenues, most MNEs will be reluctant to adopt such a policy voluntarily-or will adopt it solely to satisfy shareholders who are concerned about the social issues involved, but then fail to abide by it. At the same time, a mandated CSR regime will cause MNEs simply to change their country of registration to avoid being forced to implement it, and to thereby lose money. While the EU CSR initiative sets forth highly commendable principles, its becoming a reality is questionable, especially in light of its lack of monitoring and enforcement mechanisms. Furthermore, it creates no accountability among the MNEs to which it applies. Use of the EU effort as a case study highlights the need for stronger self-governance; however, it also begs the question of whether selfenforcement by MNEs is sufficient. The EU initiative is the best of the available alternatives at this point, as other methods have been tried and have failed.

However, before a global CSR regime such as that proposed by the EU will function to achieve sustainable development by controlling the actions of MNEs, such regime must necessarily include provisions for strict monitoring and enforcement of actions by MNEs in the home country as well as, and especially, in host developing countries where MNEs have in the past and are apt to 
continue to exploit lax environmental standards and labor regulations so as to increase their profitability. Permitting MNEs to monitor themselves is insufficient as the natural motivation of a company is to maximize profit. Indeed, corporate law tells officers and directors that their duty is to maximize shareholder wealth. Thus, a change in corporate law as well as changes in the typical directors', officers', and shareholders' mindset is crucial to the success of CSR in moving toward achieving sustainable development. Critical to the attainment of sustainable development through CSR, thus, is a paradigmatic shift in corporate and investor culture, as well as the implementation of a mandatory CSR regime that will apply globally, regardless of where the MNE is doing business, and that includes strict monitoring and enforcement mechanisms. Such an initiative is, however, illusory because of the difficulties in creating and administering the necessary mechanisms for monitoring and enforcement. Until an administrable method of enforcing CSR on MNEs is fashioned, the reality of sustainable development hinges on the unwillingness of MNEs to participate in a race-to-thebottom search for nations with lax regulations and on the ability of MNEs to conform to whatever CSR policy they may already have in their corporate guidelines. 